\title{
4 Development of a technology to prevent spontaneous combustion of coal in underground coal mining
}

\author{
by A. Tosun
}

\section{Synopsis}

Top and bottom roads, as well as the production areas in underground coal mining, are continually in contact with oxygen supplied by the mine ventilation system. These areas are at risk of spontaneous combustion, depending on various environmental conditions and characteristics of the coal seam. The formation of toxic gases as a result of spontaneous combustion of the coal and exposure of employees to these gases are the most important causes of coal mining accidents. To avoid the risk of spontaneous combustion, contact of the coal with oxygen must be prevented during production. The literature mentions various studies based on the use of fillers on small areas to control or delay spontaneous combustion. In this study, the aim was to develop cheap materials with very low oxygen permeability and high mechanical resistance for coating the walls of the mine galleries. Epoxy/fibreglass was identified as the material with the least oxygen permeability, and also has other desirable properties.

Keywords

Coal mining accidents, spontaneous combustion of coal, polymer composite materials, oxygen permeability.

\section{Introduction}

In recent years, deaths occurring as a result of underground coal mining have increased, due to serious accidents in certain regions. These accidents are mostly due to firedamp explosions and spontaneous combustion of the coal. Toxic gases are formed as a result of spontaneous combustion and many deaths may ensue due to exposure of employees to these gases. The spontaneous combustion of coal is an serious event that must be taken into consideration since it impedes production and has adverse occupational health consequences in underground mines.

Spontaneous combustion is caused by selfheating of the coal through slow oxidation, and with sufficient heat accumulation it can develop into actual combustion with open flames. Top and bottom roads as well as the production areas in underground coal mines are continually in contact with the oxygen supplied by the mine ventilation system. The coal adsorbs the oxygen, and once the the temperature reaches over $40^{\circ} \mathrm{C}$, the process transforms into a reaction and the ambient temperature increases further (Saraç, 1992). If this temperature cannot be reduced, after approximately $70^{\circ} \mathrm{C}$ the concentrations of $\mathrm{CO}$ and $\mathrm{CO}_{2}$ in the environment increase, and steam is evolved at $125^{\circ} \mathrm{C}$. When the temperature reaches the ignition temperature, the coal starts burning. Therefore, the galleries and the roads opened inside the coal faces are continually at risk of spontaneous combustion, depending on the environmental conditions and characteristics of the coal seam. To avoid this risk, contact between coal seams and oxygen must be prevented during production. Various studies have been carried out based on the use of fillers, generally consisting of cement and nitrogen, in small areas prone to fire risk to control or delay the advent of spontaneous combustion by preventing contact of the coal with oxygen. However, these studies were limited to very small areas due to the cost of the cement and nitrogen used to inertize the voids. Also, scientific studies have shown that cement cannot completely prevent the ingress of the oxygen.

In the scope of this study, the aim was to develop different materials with much lower oxygen permeability for coating the walls of the galleries in coal mines. Bearing in mind the size of the galleries, ensuring that the cost of this material is very low has been among the targets of this study. Therefore, the gas permeabilities of various cheap polymer composite materials were determined. The mechanical characteristics of the composite materials, such as stroke and friction, were also determined. The materials developed can be used to ensure that the coal seam doesn't contact with oxygen throughout the entire production process. Thus, it will be possible to minimize the occupational accidents occurring as a result of the oxidation of coal in underground mines.
* Dokuz Eylul University, Department of Mining Engineering and Bergama vocational school Bergama-Izmir, Turkey.

(c) The Southern African Institute of Mining and Metallurgy, 2017. ISSN 2225-6253. Paper received Mar. 2016; revised paper received May. 2017. 


\section{Development of a technology to prevent spontaneous combustion of coal}

\section{Literature studies}

The presence of coal and sufficient oxygen to initiate oxidation and sustain the oxidation at ambient temperature will lead to heat accumulation (Karpuz et al., 2000), depending on the characteristics and geological structure of the coal, and the mining conditions and environment (Feng, Chakravorty, and Cochrane., 1973; Kucht, Rowe, and Burgess, 1980). Generally, low-rank coals with a high pyrite content or high ratio of oxygen to moisture (semibituminous and lignites) are more prone to self-heating. Pyrite increases the risk if it is fine grained and present in sufficient quantity (Didari, 1986). The total surface area of the coal makes an important contribution to the self-heating propensity. The heating rate is directly proportional to the cube of the surface area. Thus, the more friable the coal the higher the risk of spontaneous combustion, due to the increased quantity of coal fines. Since a large amount of coal fines is produced at mechanized mines, accumulation of this material poses a potential risk. In thick seams, poor roof conditions may also create danger since the roof becomes unstable and coal accumulates on the floor. Generally, subsidence leads to cracks above the mine workings close to the surface and provokes the development of combustion by causing air leakage. Similarly, fractures in closely spaced seams cause air to leak between the seams. A high pressure difference in the ventilation is also an important factor provoking the development of self-heating. With an increase in the ventilation pressure, the possibility of heating is increased since the air leakage to a cracked coal mass or cave-in will increase. Main ventilation ways, regulators, and leakages in the gates are also a source of danger. Ground heave and roof falls also cause air leakage. If the regulators and the doors are not placed properly, they may cause air leakage into the cracks inside the coal around them due to increased pressure differential. The greater the pressure difference, the greater the risk of combustion. The amount of air in circulation in the mine is also important. As a general rule, the amount of air supplied to the oxidation zone must be sufficient to prevent the accumulation of the heat released. If a large amount of air flow is applied, the heat of oxidation is carried away but the increased oxygen supply will facilitate combustion (Demirbilek, 1986). On the other hand, if air flow is low, the heat released as a result of oxidation cannot be removed from the environment and will remain in the coal. If the fissure density, degree of cracking, and amount of broken coal are excessive, the rate of oxidation and subsequently the rate of heat production will be excessive. Therefore, it is useful to know the mine conditions inducive to self-combustion.

As soon as the coal contacts the open air, it reacts with the oxygen even at low temperatures. Besides the physical and chemical changes in the coal, the heat is released depending on absorption and adsorption capacity of each coal type. The rate of oxygen comsumption during oxidation varies depending on the time and the phase of the oxidation. In the first phase of oxidation, the oxygen intake is very rapid and peroxide complexes are formed. The oxygen consumption decreases over time due to the coating of the coal surface with oxygen compounds and the temperature approaches a constant value. However, if the coal reaches the temperature of self-heating, oxygen consumption and temperature increase rapidly. Wade (1988) indicated that the

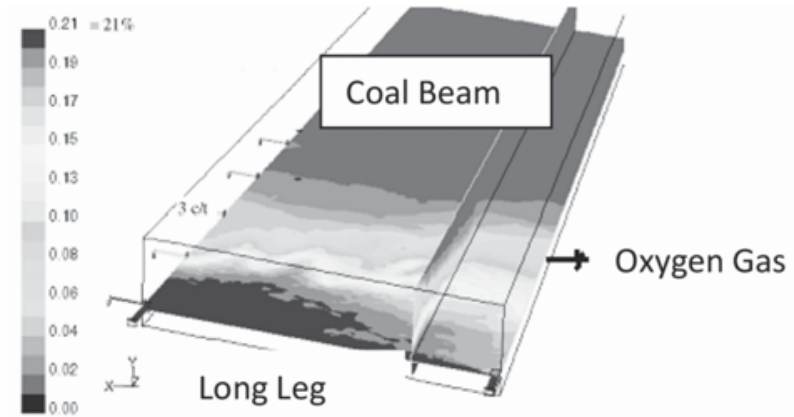

Figure 1-The oxygen distribution formed in an air flow of $50 \mathrm{~m} 3 / \mathrm{s}$ in a coal seam (Balusu et al., 2002)

factors affecting the physical oxidation ratio of the coal are particle size, temperature, moisture, pre-heating, oxygen partial pressure, volatile substance content, internal moisture, carbon content, degree of carbonization, and methane content.

Studies on the prevention of spontaneous combustion are also reported in the literature. Millions of dollars have been spent on research related to this subject in Australia (Cliff, Brady, and Watkinson, 2014). A method based on monitoring the distribution of oxygen in the coal seams was developed (Balusu et al., 2002, 2010; Ren, Balusu, and Humphries, 2005). A simulation model showing the oxygen distribution inside the coal seam can be constructed by this method, as seen in Figure 1. Thus, precautions can be taken in cases where there is a high self-heating risk. The data for the simulation model is provided through sensors located at crirical places. However, owing to breakdown of the sensors, correct readings cannot be obtained in adverse conditions. Also, the method doesn't control or prevent combustion.

The source of oxygen in the case of an underground coal mine is the mine ventilation. One aeration ventilator is generally placed at the mine entrance. Ventilator pressure varies depending on the depth of the mine and the length of the galleries. This pressure is high at mines with deep and long galleries. High air pressure creates high oxygen concentrations underground. Luxbacher and Jong (2013) reduced the ventilation pressure by using more than one ventilator. Thus, the contact of the coal with less oxygen gas is ensured, delaying spontaneous combustion.

Certain filling materials were injected into the zones with a combustion risk in order to prevent spontaneous combustion (Humphreys, 2013). Filling materials were used in the form of resin, foam, and cement. These materials reduced the passage of oxygen. The injection of nitrogen and carbon dioxide under pressure into the zones at risk of combustion has also been successful (Ray and Singh, 2007).

The abovementioned studies were based on the coating of only small areas at fire risk with various substances. Preventing contact of the entire coal seam with oxygen couldn't be ensured, except for the production area during the production period. Also, due to high cost of the nitrogen to prevent combustion and the cement filler, the coating of all coal surfaces in the underground mine with these materials is not possible. On the other hand, studies have shown that cement cannot completely exclude oxygen. 


\section{Development of a technology to prevent spontaneous combustion of coal}

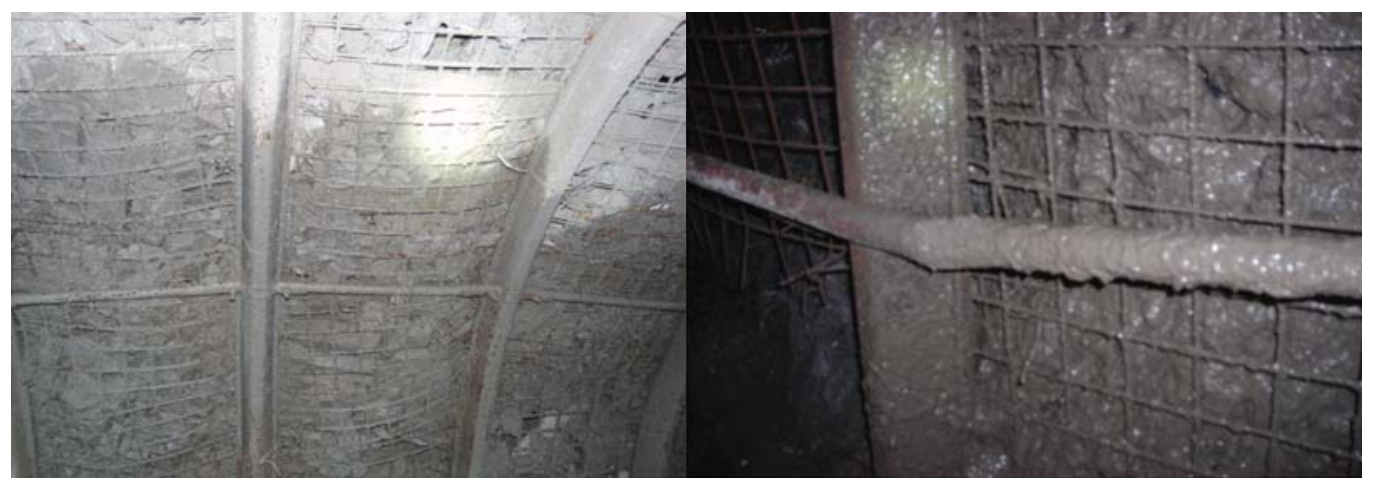

Figure 2-Application of ash, cement, and water mixture to prevent spontaneous combustion (Onur et al., 2012)

Based on this previous work, studies were carried out at Omerler underground coal mine in Tunçbilek district, Kütahya Province of Turkey. A method that would prevent spontaneous combustion of the coal seam was developed during this research (Onur et al., 2012). The mine galleries were coated using a mixture of ash, cement, and water in certain proportions and efforts were made to prevent oxygen from contacting the coal (Figure 2). It was determined that the mixture of ash, cement, and water reduced the oxygen permeability.

Polymers are materials with a low oxygen permeability. The development of polymer composite materials as a barrier layer between the coal surface and the ambient air of the mine was therefore investigated in this study.

Fibre-reinforced polymers consist of a polymer resin impregnated with low-cost fibreglass or high-cost aramid/carbon fibre materials. Fibres may be short or long, continuous or discontinuous, and single or multi-ply. Materials of this type have advantages compared with steel, aluminum, and other isotropic metals, having high stiffness, low weight, good fatigue characteristics, and corrosion resistance. Additionally, the characteristics of the materials can be tailored to the requirements of special designs by changing the orientations of the fibres. Typically the matrix materials, which harden by the evolution of heat, consist of epoxy, epoxy-based vinyl ester, and polyester resin and are used for the production of fibre-reinforced layers. However, vinyl esters modified by more flexible urethane are also used in the production of composites. These resins are normally hardened by a peroxide-based catalyser and a cobalt-based accelerator. To improve the characteristics of the composite material, the resin may be subjected to different curing procedures after the hardening process. Different fibreglass types can be used as reinforcement, including E-glass and boron-free E-glass. These materials differ in their corrosion reistance towards acid and basic substances and their tensilecorrosion strengths. Fibre-reinforced polymer materials can be produced by manual spreading or by continuous processing methods such as filament winding, spraying, and centrifuging, depending on the structure and geometry of the fibre materials. The focus in this project was to obtain high strength values and to avoid the use of easily flammable materials such as wedge-brush.

Polymers are widely used in packaging, especially for food and medicine where gas permeability, optical, and mechanical characteristics become important. These must meet challenging needs such as moisture, oxygen permeability, carbon dioxide permeability under pressure, and high-temperature sterilization. Different polymers such as polyolefin and polyethylene terephthalate (PET) are generally used in multi-layer structures to integrate their desirable characteristics (Lee, 2002). In general, these layers consist of a polyolefin folio serving as a moisture barrier and a PET folio functioning as an oxygen barrier. If adhesive material contributes to the oxygen barrier characteristic of polyolefin/PET layers, this will be advantageous. The barrier characteristics of the polymer are generally developed by obtaining a composite material through impregnation of the fibre materials not having good permeability characteristics with the polymers. Thus, the possibilities of the small oxygen molecules being able to diffuse to the other side of the composite layer by passing around the fibre materials will be minimized. Fibre-reinforced polymer materials are used in the reinforcement and the repair of structures, and many independent studies have shown that these materials are impermeable to oxygen. These applications have been effective in the repair of corrosion damage since the mid1990s (Alampalli, 2001; Pantazopoulou et al., 2001; Debaiky, Green, and Hope, 2002; Sen, 2003; Wang and Shih, 2004; Badawi and Soudki, 2005; Suh et al., 2007, 2008; Winters et al., 2008). Various studies have also shown that fibre-reinforced polymer materials do not prevent corrosion entirely, but reduce the corrosion rate considerably (Baiyasi and Harichandran, 2001; Berver et al., 2001; Wootton, Spainhour, and Yazdani, 2003; Wheat, Jirsa, and Fowler, 2005). Figure 3 shows the corrosion of an abutment caused by oxidation and the process of coating with a polymer composite material.

\section{Method and laboratory studies}

Coal is a fragile and pervious material. The oxygen gains entrance to the coal either through fissures or by diffusion from the coal surface. This situation causes the spontaneous combustion of the coal. Because oxygen molecules are very small and also undergo rapid diffusion, their permeability inside fibre-reinforced polymeric materials is critical. In the scope of this study, the oxygen permeability of the fibrereinforced polymer was investigated experimentally. This study is the first international study of the oxygen 


\section{Development of a technology to prevent spontaneous combustion of coal}

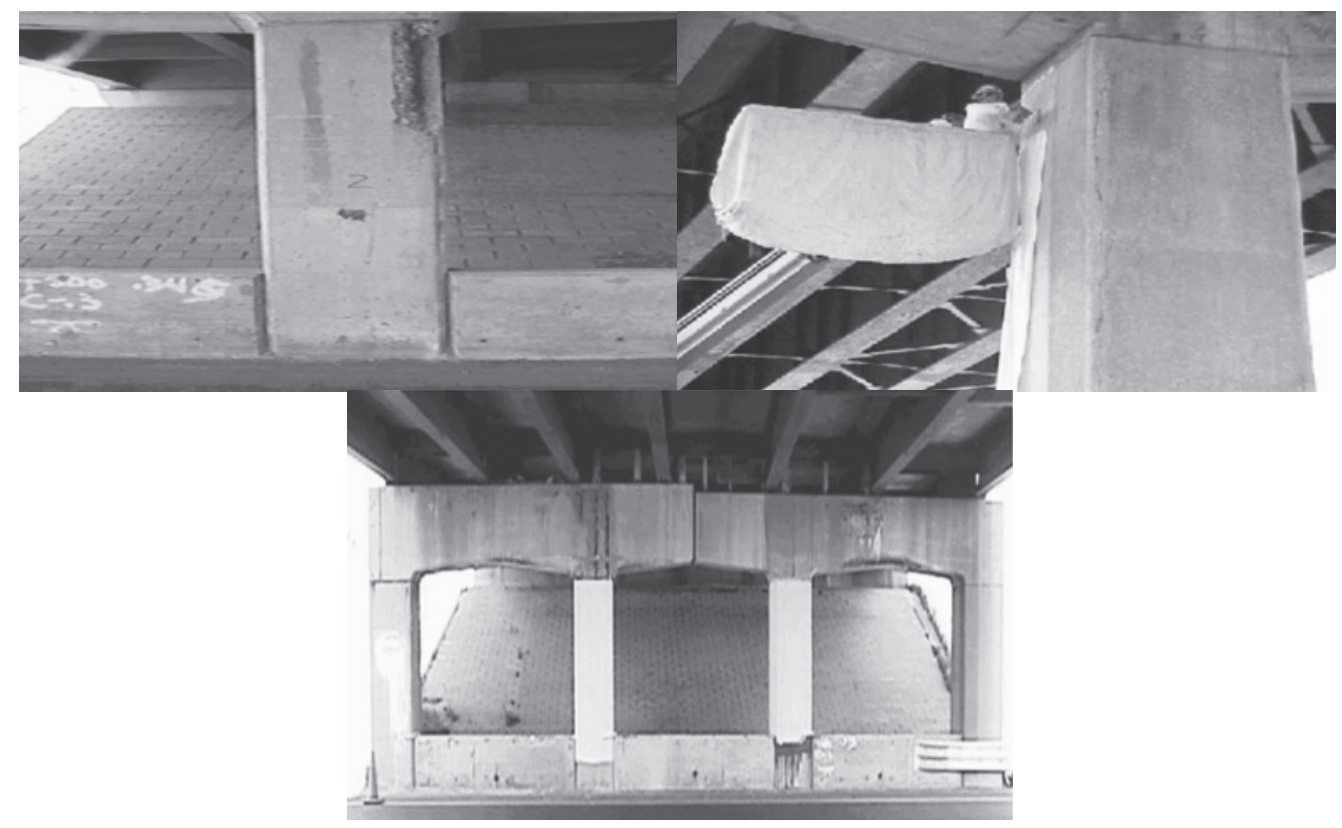

Figure 3-Corrosion of an abutment due to oxygen and the process of coating it with a composite material (Sen, 2003)

permeability of polymer composite materials for underground coal mining applications. Several types of polymer composite materials were prepared experimentally. Fibreglass produced in the form of a felt was used as an additive, since it is very cheap compared to the alternatives, namely carbon and armide, and has been very effective. Three types of polymeric resins - epoxy, polyester, and vinyl ester resins - were investigated to ascertain the effect of the polymer material

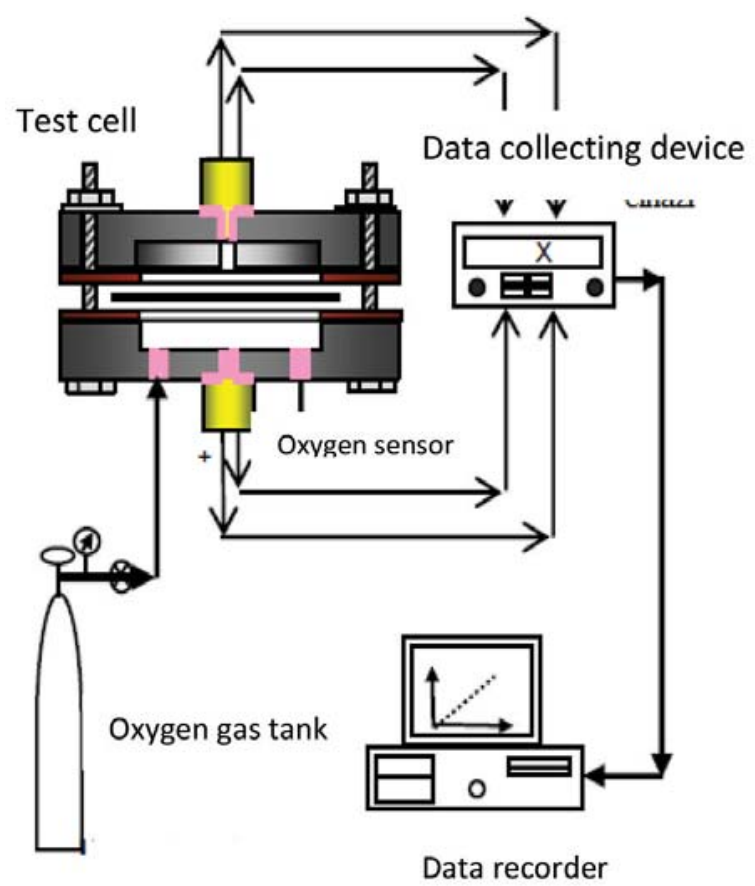

Figure 4-The method for determining the oxygen permeability of the materials (Chandra, 2011) used in the production of the composite material on the oxygen permeability.

A few methods are available for the determination of the oxygen permeability of polymers, but these are not suitable for thick materials. The oxygen permeabilities of the composite material samples produced at laboratory scale were determined using the system developed by Chandra (2011) (Figure 4). In this test device, a stream of oxygen gas is directed on the surface of the material and the amount of oxygen that diffuses to the opposite surface of the material is determined by an oxygen sensor. The volume of oxygen gas passing from the material during the test is recorded continually.

The material tested was placed in the test cell. Oxygen gas was streamed onto the sample from the oxygen tank. The oxygen gas sensor in the test cell transmitted the data on the amount of oxygen passing through the material to the data collecting device, and the data was stored in the data recorder. Thus, the degree of oxygen permeability of the material tested could be measured precisely. Each test lasted for three or four hours. The oxygen gas permeabilities determined for the materials are listed in Table I.

Table I

Oxygen gas permeabilities of the composite materials

\begin{tabular}{|l|c|c|}
\hline Material type & $\begin{array}{c}\text { Oxygen permeability } \\
\text { (mol.m²/m³.atm.sec) }\end{array}$ & Number of tests \\
\hline Epoxy/fibreglass & $5.22 \times 10-13$ & 6 \\
\hline Polyester/fibreglass & $4.02 \times 10-8$ & 4 \\
\hline Vinyl ester/fibreglass & $4.29 \times 10-11$ & 7 \\
\hline
\end{tabular}




\section{Development of a technology to prevent spontaneous combustion of coal}

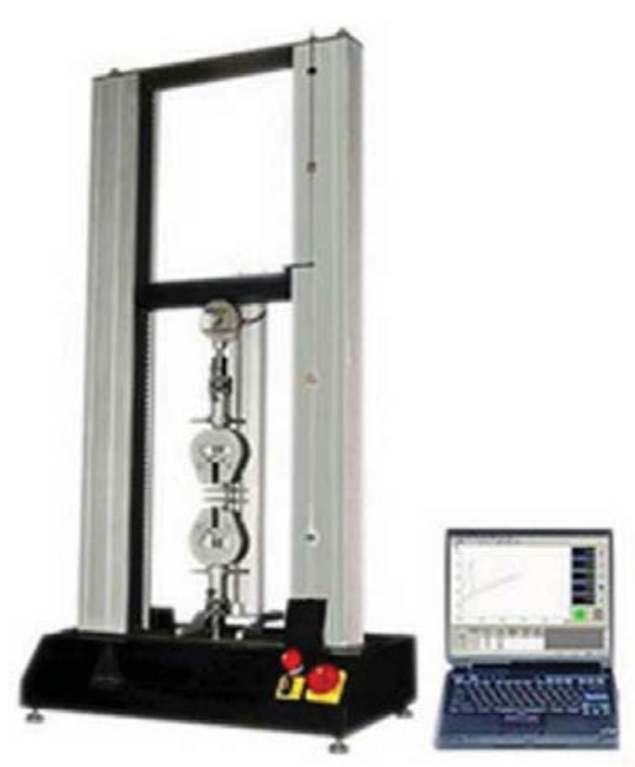

Figure 5-The system for determining the tensile strength of the composite materials

A composite polymer material intended for application in underground working conditions must also be strong. Therefore, it is also important to determine the mechanical characteristics of the composite polymer materials. The elastic modulus and the Poisson's ratios were determined by means of the tensile test, using the apparatus shown in Figure 5.

Strain gauges were fixed to the material with adhesive. The strain gauges consisted of fine washers on an elastic carrier and connected to each other in parallel. These washers extend or shorten in proportion to the load applied on the material. Deformation was recorded continually by the data recorder. The first increase in the force applied on the material must be regular. Therefore, pre-loading was carried out and the force was increased slowly. At the end of the test, the elasticity modulus and the Poisson's ratio were determined for each material by averaging the longitudinal and axial deformations measured continually (Table II). The following relationships were used in the determination of these values.

$$
\begin{aligned}
& \sigma=\frac{\mathrm{P}}{\mathrm{A}} \\
& E=\sigma / \varepsilon \\
& \nu=-\left(\varepsilon_{1} / \varepsilon_{2}\right)
\end{aligned}
$$

where

$\sigma=$ Tensile strength $(\mathrm{MPa})$

$E=$ Elastic modulus (MPa)

$v=$ Poisson's ratio

$\varepsilon_{1}=$ Lateral deformation

$\varepsilon_{2}=$ Vertical deformation
Table II

Mechanical strengths of the materials

\begin{tabular}{l|c|c|c|}
\hline Material type & $\begin{array}{c}\text { Elastic modulus } \\
\text { (MPa) }\end{array}$ & $\begin{array}{c}\text { Poisson's } \\
\text { ratio }\end{array}$ & $\begin{array}{c}\text { Number } \\
\text { of tests }\end{array}$ \\
\hline Epoxy/fibreglass & 3802 & 0.274 & 13 \\
\hline Polyester/fibreglass & 6546 & 0.225 & 18 \\
\hline Vinylester/fibreglass & 2756 & 0.336 & 11 \\
\hline
\end{tabular}

\section{Evaluation}

The epoxy/fibreglass composite was identified as having the least oxygen permeability of the materials tested. All gallery surfaces in the underground coal workings can be coated with this material to impede the permeation of oxygen gas during production and prevent spontaneous combustion of the coal. Thus, reduced levels of dangerous gases can be ensured inside the mines through minimized spontaneous combustion reactions.

The permeability constant is defined as the rate per unit area at which a gas passes through a material of unit thickness under one unit pressure difference, expressed in units of mol.m2/ $\mathrm{m}^{3}$.atm.sec. Thus underground coal mining companies can calculate how much oxygen gas will enter the coal seam by substituting their ventilator pressure, the size of coal seams, and time. This will indicate when the spontaneous combustion of the coal will start according to the combustion properties of the particular coal.

The materials used in the study were produced in the solid state in the laboratory environment. For use in underground conditions, they must be produced in liquid form so that they can be sprayed onto the gallery surfaces. The surfaces of coal galleries are generally very irregular, and it will be necessary to ensure thorough coating of all surfaces and discontinuities. The application of the materials in underground conditions and the determination of the performances of the materials under these conditions should be investigated in future studies.

\section{Summary and conclusions}

The aim of this study was to develop cost-effective materials with very low oxygen permeability and high mechanical resistance for coating the walls of the galleries in underground coal mines in order to prevent spontaneous combustion of the coal. Three types of composite material were manufactured for testing. All of them were found to have good mechanical properties as well as being cheap to manufacture. The epoxy/fibreglass composite was identified as the material with the lowest oxygen permeability. The cost of this material (weight of $80 \mathrm{~g} / \mathrm{m}^{2}$ ) is US\$0.124-0.209 (https://cnxinghao.en.alibaba.com/product/60601388436219 069229/80g_m2_fiberglass_price_epoxy_fiberglass_resin_bit umen.html). This study is the first international study to determine the oxygen permeability of polymer composite materials for use in underground coal mining. 


\section{Development of a technology to prevent spontaneous combustion of coal}

\section{References}

Alampalli, S. 2001. Reinforced polymers for rehabilitation of bridge columns. Proceedings of the 5th National Workshop on Bridge Research in Progress, 8-10 October. University of Minnesota. pp. 39-41.

BADAWI, M. and SoUDKI, K. 2005. Control of corrosion-induced damaged in reinforced concrete beams using carbon fiber-reinforced polymer laminates. Journal of Composites for Construction, vol. 9, no. 2. pp. 195-201.

BAIYASI, M. and HARICHANDRAN, R. 2001. Corrosion and wrap strains in concrete bridge columns repaired with FRP wraps. Proceedings of the 80th Annual Meeting, Transportation Research Board, Washington, DC. Paper no. $01-$ 2609.

Balusu, R., Ren, T., Schiefelbein, K., O'Grady, P., and Harvey, T. 2010. Proactive strategies to prevent fires and explosions in longwall mines. $A$ century of Mining Research. SME, Littleton, CO. pp. 408-417.

Balusu, R., Humphries, P., Harrington, P., Wendt, M., and Xue, S. 2002. Optimum inertisation strategies. Proceedings of the Queensland Mining Industry Safety and Health Conference, Townsville. pp. 133-144.

Berver, E., JiRsa, J., Fowler, D., WheAt, H., and Moon, T. 2001. Effects of wrapping chloride contaminated concrete with fiber reinforced plastics. Report no. FHWA/TX-03/1774-2. enter for Transportation Research, University of Texas, Austin.

CHANDRA, K.K. 2011. Oxygen diffusion characterization of FRP composites used in concrete repair and rehabilitation. Doctoral thesis, University of South Florida..

Cliff, D., Brady, D., and Watkinson, M. 2014. Developments in the management of spontaneous combustion in Australian underground coal mines. Proceedings of the 2014 Coal Operators' Conference, University of Wollongong. Australasian Institute of Mining and Metallurgy, Melbourne.

David, C., Darren B., and MarTin W. 2014. Developments in the management of spontaneous combustion in Australian underground coal mines. Proceedings of the 2014 Coal Operators' Conference, University of Wollongong. Australasian Institute of Mining and Metallurgy, Melbourne.

Debaiky, A., Green, M., and Hope, B. 2002. Carbon fiber-reinforced polymer wraps for corrosion control and rehabilitation of reinforced concrete columns. ACI Materials Journal, vol. 99, no. 2. pp. 129-137.

DemirвiLeK, S. 1986. The development of a spontaneous combustion risk classification system for coal seams. PhD thesis, University of Nottingham, UK.

DIDARI, V. 1986. Yeraltı ocaklarında kömürün kendili inden yanması ve risk indeksleri. (Spontaneous combustion and risk indices in underground mines). Madencilik, vol. 15, no. 4. pp. 29-34.

Feng, K.K., Chakravorty, R.N., and Cochrane, T.S. 1973. Spontaneous combustion - a coal mining hazard. CIM Bulletin, vol. 66. pp.75-84.

HuMPHREYs, D. 2013. Scoping Study: Application of new forms of fire suppression and hydrocarbon absorption materials to underground coal mines. Final Report C21015. Australian Coal Industry Research Program, Brisbane.

Karpuz, C., Güyagüler, T., BaĞci, S., Bozdač, T., Başarir, H. and Keskin, S. 2000. Linyitlerin kendili inden yanmaya yatkınlık derecelerinin tespiti: bölüm 1 - risk sınıflaması derlemesi. (The determination of liability index for spontaneous combustion of lignite: Part 1- Risk classification review). Madencilik dergisi Sayl, vol. 39, no. 3-4. pp.3-13.

KuchTA, J.M., RowE, V.R., and BuRgess, D.S. 1980. Spontaneous combustion susceptibility of U.S. coals. Report of Investigation RI8474. US Bureau of Mines.

LEE, S. 2002. The Polyurethane Book. Wiley, New York.

LUXBACHER, K. and Jong, E. 2013. Development of a passive tracer gas source for mine ventilation applications. Proceedings of the 24th Annual General Meeting of the Society of Mining Professors, Milos Island, Greece. pp. 26-99.
OnuR, A.H., Köse, H., Yalçin, E., KonaK, G., Yenice, H., Karakus, D., Gönen, A., Tosun, A., and ÖzDočAn, M. V. 2012. Türkiye kömür i letmeleri-güney linyitleri i letmesi (TK -GL) müessesesi Ömerler yeraltı oca l tavan kontrolü-tahkimat tasarimı ve ocak yanginlarn Ar-Ge Projesi.

Pantazopoulou, S.J., Bonacci, J.F., Sheikh, S., Tomas, M.D.A., and Hearn, N. 2001. Repair of corrosion-damage columns with FRP wraps. Journal of Composites for Construction, vol. 5, no. 1. pp. 3-11.

RAY, S.K. and SinGH, R.P., 2007. Recent developments and practices to control fire in underground coal mines. Fire Technology, vol. 43. pp. 285-300.

Ren, T.X., Balusu, R., and Humphries, P. 2005. Development of innovative goa inertisation practices to improve coal safety. Proceedings of Coal 2005: Coal Operators' Conference, University of Wollongong. Aziz, N (ed). Australasian Institute of Mining and Metallurgy, Melbourne. pp. 315-322.

RESTREPol, J.I. and DeVIno, B. 1996. Enhancement of the axial load carrying capacity of reinforced concrete columns by means of fiberglass-epoxy jackets. Proceedings of the First International Conference on Composites in Infrastructure, Montreal. Canadian Society for Civil Engineering. pp. $547-553$.

Samaan, M., Mirmiran, A., and Shahawy, M. 1998. Model of concrete confined by fiber composites. Journal of Structural Engineering, ASCE, vol. 124, no. 9. pp. $1025-1031$.

SARAç, S., and SoYTüRK, T. 1992. Tunçbilek kömürlerinin kendili inden yanmaya yatkınlıklarının ara tırılması. (An investigation on the liability of Tunçbilek coals to spontaneous combustion.) Türkiye 8. Kömür Kongresi Bildiriler Kitabl. pp. 141-152.

Sen, R, Mullins, G., and Snyder, D., 1999. Ultimate capacity of corrosion damaged piles. Final Report submitted to Florida Department of Transportation.

SEN, R. 2003. Advances in the application of FRP for repairing corrosion damage. Progress in Structural Engineering and Materials, vol. 5, no. 2. pp. 99-113.

Sheikh, S., Pantazopoulou, S., Bonacci, J., Thomas, M., and Hearn. N. 1997. Repair of delaminated circular pier columns with advanced composite materials. Report no. 31902. Ontario Joint Transportation Research, Toronto, Ontario, Canada.

SuH, K., Muluins, G., Sen, R., and WinTERS, D. 2007. Effectiveness of FRP in reducing corrosion in a marine environment. ACI Structural Journal, vol. 104, no. 1. pp. 76-83.

SuH, K.S., SEN, R., Mullins, D., and Winters, D. 2008. Corrosion monitoring of FRP repaired piles in tidal waters. Special Publication 252. American Concrete Institute. pp. 137-156.

TARRicone, P. 1995. Composite sketch. ASCE, Civil Engineering Magazine. pp. $52-55$.

WADE, L. 1988. The propensity of South African coals to spontaneously combusti. PhD thesis, University of the Withwaterstrand, Johannesburg.

WANG, C. and SHIH, C. 2004. Rehabilitation of cracked and corroded reinforced concrete beams with fiber-reinforced plastic patches. Journal of Composites for Construction, vol. 8, no. 3. pp. 219-228.

WHEAT, H.G., JiRSA, J.O., and FowLER, D.W. 2005. Monitoring corrosion protection provided by fiber reinforced composites. International Journal of Materials and Product Technology, vol. 23, no. 3-4. pp. 372-388.

Winters, D., Mullins, G., Sen. R., and Stokes, M. 2008. Bond enhancement for FRP pile repair in tidal waters. ASCE, Journal of Composites for Construction, vol. 12, no. $334.10 \mathrm{pp}$

Wootton, I., Spainhour, L., and YazDani, N. 2003. Corrosion of steel reinforcement in CFRP wrapped concrete cylinders. Journal of Composites for Construction, vol. 7, no.4. pp. 339-347. 